surgery in children. ${ }^{5}$ In our study, ${ }^{1}$ we could not elucidate the exact mechanism of the deterioration of $\mathrm{RV}$ performance. As suggested by Koestenberger and colleagues, however, we hope that our findings encourage future research and routine follow-up of RV performance after correction of congenital heart defects. ${ }^{5}$

Liselotte M. Klitsie, MSc Arno A. W. Roest, MD, PhD

Nico A. Blom, $M D, P h D$

Arend D. J. Ten Harkel, MD, PhD Department of Pediatric Cardiology Leiden University Medical Center Leiden, The Netherlands

\footnotetext{
References

1. Klitsie LM, Roest AA, Kuipers IM, Hazekamp MG, Blom NA, Ten Harkel AD. Left and right ventricular performance after arterial switch operation. J Thorac Cardiovasc Surg. September 12, 2013 [Epub ahead of print].

2. Eidem BW, McMahon CJ, Cohen RR, Wu J, Finkelshteyn I, Kovalchin JP, et al. Impact of cardiac growth on Doppler tissue imaging velocities: a study in healthy children. $J$ Am Soc Echocardiogr. 2004;17:212-21.

3. Koestenberger M, Ravekes W, Everett AD, Stueger HP, Heinzl B, Gamillscheg A, et al. Right ventricular function in infants, children and adolescents: reference values of the tricuspid annular plane systolic excursion (TAPSE) in 640 healthy patients and calculation of $z$ score values. J Am Soc Echocardiogr. 2009;22:715-9.

4. Koestenberger M, Nagel B, Ravekes W, Avian A, Heinzl B, Cvirn G, et al. Reference values of tricuspid annular peak systolic velocity in healthy pediatric patients, calculation of $z$ score, and comparison to tricuspid annular plane systolic excursion. Am J Cardiol. 2012;109:116-21.

5. Klitsie LM, Hazekamp MG, Roest AA, Van der Hulst AE, Gesink-van der Veer BJ, Kuipers IM, et al. Tissue Doppler imaging detects impaired biventricular performance shortly after congenital heart defect surgery. Pediatr Cardiol. 2013;34: 630-8.
}

http://dx.doi.org/10.1016/ j.jtcvs.2013.12.026

\section{DISTAL IN SITU PEDICLED (NONSKELETONIZED) INTERNAL THORACIC ARTERY GRAFT}

\section{To the Editor:}

I have read with interest the report by Toeg and Rubens ${ }^{1}$ that has recently been published, discussing the semantics of the adjectives "pedicled," "skeletonized," and the Latin term "in situ," regarding their use in the description of internal thoracic artery (ITA) harvesting and coronary grafting techniques.

It is easy to accept that the terms "skeletonized" and "nonskeletonized" appropriately reflect the degree of isolation of the ITA from the surrounding tissue of the conduit. ${ }^{1}$ However, I can hardly agree with the statement that the pedicled graft represents an ITA conduit in which the proximal connection of the conduit to the subclavian artery is preserved, but that when it is divided, it is a free graft. ${ }^{1}$

Actually, Kolesov and Petukhov ${ }^{2}$ were the first who used a reversed left ITA (LITA) conduit (LITA transected near its origin and thus supplied by retrograde flow from the superior epigastric and musculophrenic arteries), and Kolesov even protected his author's right (patent no. 388738-13.04.1973.) for the reversed LITA-left anterior descending (LAD) coronary artery anastomosis. We have recently reported excellent early results using the inverted LITA conduit to revascularize the LAD in carefully selected patients. ${ }^{3-5}$

In 1 patient, we used a simple and practical technique of splitting the LITA graft and using its proximal and distal parts to revascularize the LAD coronary artery bed. ${ }^{3}$ The proximal, in situ (with the origin of the ITA still "in its original place"), nonskeletonized LITA was used to revascularize the large diagonal branch in a classic fashion, and the distal, in situ (with the branching of the ITA and the superior epigastric and musculophrenic arteries still "in their original places"), nonskeletonized LITA revascularized the LAD in a retrograde fashion. ${ }^{3}$ Furthermore, we have reported a case of accidental damage of the proximal LITA during harvesting ${ }^{4}$ and intentionally division of the LITA near its origin to avoid all complications to which the classically routed nonskeletonized LITA conduit would be exposed in a patient with a grossly emphysematous lung. ${ }^{5}$ Although in both cases, ${ }^{4,5}$ the proximal LITA connections were divided from the subclavian artery, according to Toeg and Rubens, ${ }^{1}$ we should have termed them free grafts, but, obviously, they are not. Therefore, I would suggest, if anyone at all would like to change the present nomenclature, to use the term "distal in situ nonskeletonized ITA" for reversed ITA conduits, instead of "free ITA graft," as called by Toeg and Rubens. ${ }^{1}$

Dusko Nezic, MD, PhD, FETCS

Department of Cardiac Surgery

"Dedinje" Cardiovascular Institute

Belgrade, Serbia

\section{References}

1. Toeg HD, Rubens FD. Pedicled versus in situ internal thoracic artery: a petition for consistency in communication (editorial). J Thorac Cardiovasc Surg. 2014;147:4-5.

2. Kolesov VI, Petukhov IuA. Retrograde mammarycoronary anastomosis and its place among other methods of myocardial revascularization. Vestn Khir Im I I Grek. 1976;116:7-13.

3. Nezic D, Antonic Z, Knezevic A, Bojovic Z. Split, in situ left internal thoracic artery to revascularize left anterior descending coronary artery system. $J$ Thorac Cardiovasc Surg. 2011;142:1579-80.

4. Nezic D, Antonic Z, Bojovic Z, Milicic M, Boricic M, Kecmanovic V, et al. How to use the lef internal thoracic artery which has been damaged during harvesting? Ann Thorac Surg. 2012;94:269-71.

5. Nezic D, Bojovic Z, Kecmanovic V, Boricic M, Milacic P, Lausevic-Vuk L. Coronary artery surgery in a patient with grossly emphysematous lung. Asian Cardiovasc Thorac Ann. July 16, 2013 [Epub ahead of print].

http://dx.doi.org/10.1016/ j.jtcvs.2013.11.064

\section{Reply to the Editor:}

We read with interest the letter of Dr Nezic, in which he disagreed with the concepts presented in our recent editorial. In fact, Dr Nezic's arguments conclusively support the need for a determined effort to police the use of English, and in this case Latin.

We reviewed the articles that $\mathrm{Dr}$ Nezic's team has published. In the 
first, ${ }^{1}$ they referred to the "in situ left internal thoracic artery." The term in situ is a Latin phrase meaning "in position." In their article, they said that the internal thoracic artery was divided and then the 2 ends were swung on pedicles to anastomose with 2 coronary sites. Because parts of the arterial segments were moved from their original position, they were no longer in situ, and the authors' use of this terminology is therefore incorrect. A more consistent description would refer to both conduits as pedicled, nonskeletonized, and based on proximal and distal pedicles for their blood supply.

The same error related to the incorrect use of the term in situ appears to have occurred in the second article from Dr Nezic's group. ${ }^{2}$ On examination of the diagram, it would appear that the conduit was a pedicled nonskeletonized internal thoracic artery that was based on a distal pedicle as the blood supply. We would not refer to the described conduit as free because it was left attached to its original circulatory connection, although unusually in this case the connection was distal.

We are unable to comment on the third quoted article because it is in press at our writing.

We thank Dr Nezik for drawing attention to the ongoing confusion that can plague surgical communications, and we hope that these conversations will highlight the need for standardization and strict editorial attention in our journals.

Hadi Toeg, MD

Fraser Rubens, MD, MSc, FACS, FRCSC

University of Ottawa Heart Institute Ottawa, Ontario, Canada

\footnotetext{
References

1. Nezic D, Antonic Z, Knezevic A, Bojovic Z. Split, in situ left internal thoracic artery to revascularize left anterior descending coronary artery system. $J$ Thorac Cardiovasc Surg. 2011;142:1579-80.
}

2. Nezic D, Antonic Z, Bojovic Z, Milicic M, Boricic M, Kecmanovic V, et al. How to use the left internal thoracic artery which has been damaged during harvesting? Ann Thorac Surg. 2012;94:269-71.

http://dx.doi.org/10.1016/ j.jtcvs.2013.12.027

\section{A LOT OF DRUGS AND NOT MUCH OXYGEN: IS THE COCKTAIL RESPONSIBLE FOR DELIRIUM?}

\section{To the Editor:}

We read with great interest the article by Arenson and colleagues ${ }^{1}$ that analyzed the risk factors for postoperative delirium, with particular reference to the influence of intensive care unit environment, in a large study population undergoing cardiac surgery. In their multivariate analysis, postoperative delirium was significantly associated with preoperative (eg, age, preadmission use of benzodiazepine), intraoperative (eg, combined coronary artery bypass grafting and valve surgery), and postoperative (eg, stroke or transient ischemic attack, mechanical ventilation $>24$ hours, blood transfusion, postoperative renal insufficiency) risk factors. These findings confirm the multifactorial triggers and causes of this neurologic complication and may contribute to its prevention and better management of this phenomenon. In particular, Arenson and colleagues ${ }^{1}$ found an influence of intensive care environment in patients younger than 65 years. We agree with Inouye ${ }^{2}$ that a substantial proportion of delirium is preventable through appropriate care and attention. In a study of our group that used near-infrared spectroscopy for cerebral saturation monitoring, a higher incidence of postoperative delirium was observed in patients with a bispectral index reduction more than $25 \%$ from baseline. ${ }^{3}$

Near-infrared spectroscopy is routinely used in many centers as a monitor for depth of anesthesia. Regardless of the causes of cerebral oxygen desaturation (excessive anesthetic depth, bypass flow set too low, inadequate selective cerebral perfusion), near-infrared spectroscopy allows detection of periods of decreased oxygen delivery to the brain or of critical thresholds of oxygen delivery and can help predict postoperative stroke and delirium or cerebral ischemia. ${ }^{3}$ Our study was aimed at evaluating alternatives for improving the outcomes of this patient subset. The detection of reduced cerebral oxygen saturation during surgery may change the management of these patients, leading to the development of specific treatment protocols (eg, prolonged weaning with presence of family members, delayed mobilization, differentiated analgesia). As hypothesized by Martin and coworkers, ${ }^{4}$ delirium may be related to changes in the blood-brain barrier that occur in response to systemic inflammation after cardiopulmonary bypass, even though reduced risks were not observed in patients undergoing off-pump bypass surgery. We strongly believe that the integrity of the blood-brain barrier may be compromised as a result of paradoxic pharmacologic effects: in common clinical practice, delirious patients often receive a wide range of active compounds targeting different receptors (analgesics, sedatives, antipsychotics) during both the diurnal and nocturnal periods. A disrupted bloodbrain barrier can allow drugs to enter the brain in variable quantities. Because of pharmacologic interactions not yet fully understood, in particular those related to the use of benzodiazepines, such a drug cocktail may have the paradoxic effect of worsening the delirium. ${ }^{5}$ This interpretation is compatible with findings of Arenson and colleagues ${ }^{1}$ and motivates an attention to preventive measures. Our contribution aims to add value to the debate regarding delirium prevention and management: the use of near-infrared spectroscopy, the implementation of 